\title{
USPOSTAVA OTOČKOG DISTRIBUCIJSKOG LANCA KAO PREDUVJET ODRŽIVOG POLJOPRIVREDNOG RAZVOJA STAROGRADSKOG POLJA
}

Vinko Tarbušković, Želimir Dulčić, Stefan Gelineo i Milan Vranković

Vinko Tarbušković Javna ustanova Agencija za upravljanje Starogradskim poljem, Vukovarska cesta 2, 21460 Stari Grad e-mail: stari.grad.plain@gmail.com

Želimir Dulčić Ekonomski fakultet, Sveučilište u Splitu Cvite Fiskovića 5, 21000 Split

Stefan Gelineo Marina Sabića 10, 21460 Stari Grad

Milan Vranković

Vrankovića dvor 6, Dol, 21460 Stari Grad

Sažetak:

Glavni je cilj ovoga rada odgovoriti na dva istraživačka pitanja: a) jesu li poljoprivredna obiteljska gospodarstva (OPG) zainteresirana za uspostavu učinkovitog tržnog lanca i b) ima li trenutna ekonomska vrijednost na otoku Hvaru potencijal za formiranje proizvođačke organizacije. Polazište su glavne karakteristike hvarske poljoprivrede u ovom trenutku: niska produktivnost, usitnjena proizvodnja, nepostojanje udruženosti obiteljskih poljoprivrednih proizvodača, kao i nedostatak otkupnih centara. Metodologija korištena u radu uključuje analizu dostupnih pokazatelja o količini poljoprivredne proizvodnje na otoku Hvaru i online anketni upitnik kojim su istražena mišljenja poljoprivrednih proizvođača. Rezultati analize pokazuju opravdanost definiranja teoretskog modela koji uključuje „otočki distribucijski lanac" $i$ „Agro Hub". Definirani model prikazan u radu temelji se na uspješnim primjerima razvoja distribucijskih centara za poljoprivredne proizvode koji bi mogli biti primijenjeni na otoku Hvaru. Rezultati implementacije predloženog modela uvelike bi unaprijedili poljoprivrednu proizvodnju Starogradskog polja koja se neprekidno odvija već 2.400 godina, zbog čega je i uvrštena na UNESCO-ovu listu svjetske baštine.

Ključne riječi: otočki distribucijski lanac, Starogradsko polje, obiteljsko poljoprivredno gospodarstvo, Agro Hub, poljoprivredna proizvodnja

\section{UVOD}

Poljoprivredna proizvodnja Starogradskog polja neprekidno postoji već duže od 2.400 godina, kada su jonski Grci (Slika 1) uspostavili katastarske podjele i započeli orga- 
nizirani uzgoj žita, maslina i vinove loze. Uz ove kulture uzgajali su i smokve, šipak, bademe, rogač te razne mahunarke (Kirigin i Slapšak, 2010:136). Starogradsko polje zauzima prostor otprilike 1.350 ha obradive površine i čini najveću plodnu ravnicu na hrvatskim otocima (Kirigin i Slapšak, 2010:135). ${ }^{1}$

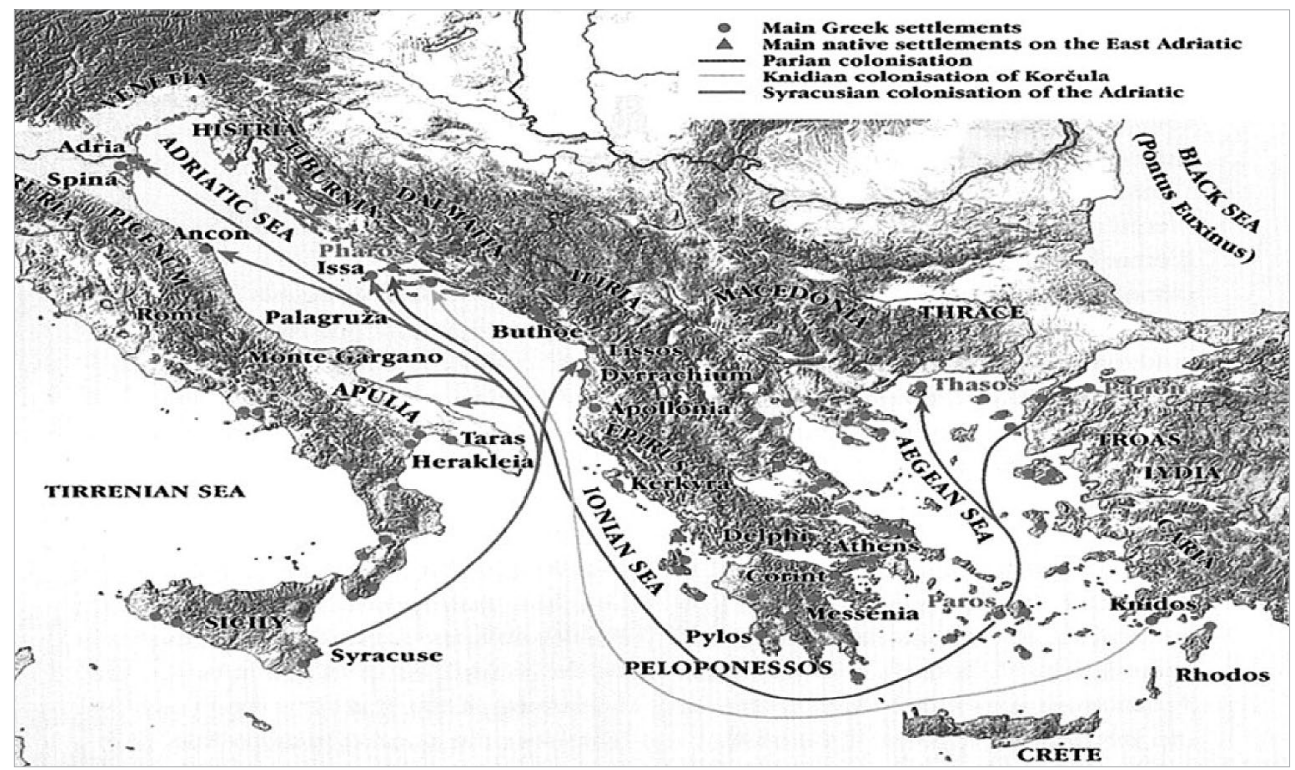

Slika 1. Grčka kolonizacija Jadrana i otoka Hvara (Izvor: Agencija za upravljanje Starogradskim poljem, 2020a)

Plodno Starogradsko polje snažan je potencijal otoku Hvaru za razvoj poljoprivrede. Nažalost, po grubim je procjenama oko $60 \%$ Starogradskog polja neobrađeno, što predstavlja veliki problem u povećanju poljoprivredne proizvodnje otoka (Plan upravljanja Starogradski Ager, 2006). S razvojem turizma na otoku Hvaru u 20. stoljeću poljoprivredna proizvodnja opada, a radno stanovništvo aktivnosti vezane za uzgoj vinove loze i maslina zamjenjuje turističkom djelatnošću. Prema statističkim podacima u današnje vrijeme najviše se uzgajaju masline, vinova loza i lavanda (Agencija za plaćanja u poljoprivredi, ribarstvu i ruralnom razvoju, 2019). Poljoprivreda također konstantno gubi važnost u gospodarstvu otoka Hvara zbog dugogodišnjih nepovoljnih procesa, a to se naročito odnosi na depopulaciju otoka uz iseljavanje mlade populacije. Veličina je posjeda relativno mala te smanjenjem raspoloživih poljoprivrednih površina i poljoprivredna proizvodnja postaje još manja. Međutim, s obzirom na specifičnost Starogradskog polja kao kulturne baštine, male površine ne moraju biti limitirajući čimbenik proizvodnje jedino ako se poljoprivredna proizvodnja temelji na dodanoj vrijednosti proizvoda, što

\footnotetext{
1 Istraživanje je provedeno u sklopu Javne ustanove Agencija za upravljanje Starogradskim poljem čiji je prvi autor ravnatelj, dok ostali autori nisu u povezanosti sa Agencijom te nemaju nikakve materijalno financijske poveznice s njom. Autori deklariraju da ni oni ni ustanova nemaju nikakvu financijsku ili drugu korist od ovog istraživanja.
} 
može omogućiti tzv. „otočki distribucijski lanac“ (ODL) (Radinović i sur., 2004). Temelj ODL-a definiran je kroz „kratke opskrbne lance“ (KOL). Iako postoji veliki broj definicija KOL-a, može se izvući jedna zajednička karakteristika: oni predstavljaju smanjen broj posrednika između poljoprivrednika ili proizvođača hrane i potrošača (Jarzębowski i sur., 2020). Isto tako, KOL doprinosi poboljšanju lokalnog razvoja, što također karakteriziraju kratka zemljopisna udaljenost između proizvođača i potrošača i bliski socijalni odnosi između proizvođača, prerađivača i potrošača (EIP-AGRI, 2015). Postavljena istraživačka pitanja nam predstavljaju glavni temelj rada kako bismo dobili potrebne inpute za definiranje teoretskog modela „ODL-a i Agro Hub-a“. Agro Hub se može definirati kao poslovna organizacija koja se bavi otkupom, plasmanom i marketingom poljoprivrednih proizvoda koji su otkupljeni od OPG-a kako bi oni lakše zadovoljili potrebe plasmana prema većim firmama ili krajnjim korisnicima (National Agricultural Library, 2020). Cilj je ovoga rada opisati teoretski model uspostave ODL-a kroz koji bi se omogućilo stvaranje adekvatne poslovne i logističke infrastrukture za povećanje, kako proizvodnje tako i plasmana otočkih proizvoda. $S$ obzirom na stupanj razvijenosti turizma, smatra se da bi lokalno proizvedeni poljoprivredni proizvodi morali naći svoje mjesto u hvarskom ugostiteljsko-turističkom sektoru i na tržištima van otoka. Nadalje, kroz rad će biti objašnjeno koliko je bitno udruživanje OPG-a, uspostava robne marke pod kojom se mogu lakše plasirati proizvodi, te uspostave Agro Hub-a kao centralnog mjesta putem kojeg bi se vršio otkup, plasiranje proizvoda, nabavka repromaterijala i educiranje OPG-a. U radu će isto tako biti prikazani i postojeći sustavi pametne poljoprivrede kako bi OPG-ovi unaprijedili i modernizirali svoju poljoprivrednu proizvodnju poštujući EU ideju „zelene digitalne tranzicije“ (Nacionalna razvojna strategija, 2020). Iako trenutna razina hvarske poljoprivrede nije zadovoljavajuća, kod definiranja ODL-a mora se uskladiti s nacionalnim planovima za poljoprivredu, ali i drugim planovima kojima će se implementirati europski tzv. „Green deal“ (Slika 2).

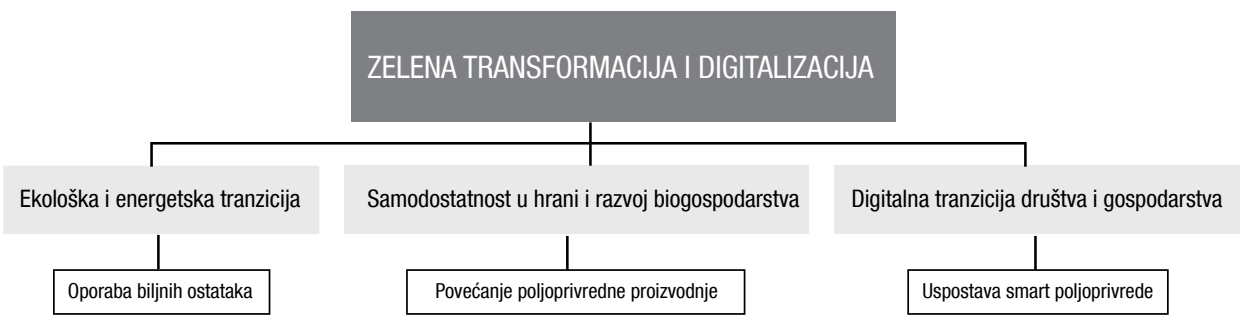

Slika 2. Zelena transformacija i digitalizacija (Izvor: autori)

Iako teoretski postavljen, ovaj rad predstavlja početak razmatranja hvarske poljoprivrede i može biti poticaj daljnjim istraživačima na dodatno produbljivanje i pronalaske rješenja za revitalizaciju i povećanje poljoprivredne proizvodnje na otoku Hvaru.

Sadržaj rada podijeljen je u šest poglavlja. Prvi je uvodni dio u kojem su definirani predmet, cilj i metode rada. Drugo poglavlje opisuje metodologiju istraživanja. Treće po- 
glavlje donosi rezultate koji se sastoje od: analize ekonomskih vrijednosti poljoprivredne proizvodnje na otoku Hvaru, rezultata ankete te je opisan model ODL-a. Četvrto je poglavlje diskusija rezultata iz trećeg poglavlja. Peto je poglavlje zaključak.

\subsection{Povijesni presjek razvoja Starogradskog polja}

Starogradsko je polje kulturni krajolik oblikovan tijekom zadnjih 2.400 godina. S obzirom na udaljenost od otoka Parosa, stari Grci morali su uspostaviti novi tržni lanac kako bi prehranili stanovništvo, ali i sebi osigurali samodostatnost poljoprivrednih proizvoda za duže razdoblje u slučaju bilo kakvih neprilika. Stoga možemo zaključiti da poljoprivredni opskrbni lanac Starogradskog polja traje neprekidno preko 2.400 godina, što ga uvrštava u jedan od najstarijih kontinuiranih lanaca u ovom dijelu svijeta (Starogradsko polje, 2012). Zbog te povijesne činjenice u daljnjem ćemo ga tekstu nazivati „otočki distribucijski lanac" (ODL).

Temelje su mu dakle udarili Grci podijelivši ga na pravilne parcele, strige, duljine 1x5 stadija (180x900 m) (Stari Grad, 2020). I drugi su ga narodi i kulture oblikovali prema svojim potrebama i načinu života. Tako Rimljani starogradsko polje Ager Farensis, kako ga oni nazivaju, preuzimaju i koriste u svoje gospodarske svrhe. Tamo grade vile rustike i gospodarsko-ladanjske objekte. U kasnoj se antici i ranom srednjem vijeku, polje obrađuje te prehranjuje novopridošlo hrvatsko stanovništvo na otoku. Dokaz tome je „Hvarski statut“ iz 1331. godine, pravni dokument Hvarske komune, koji polje spominje pod nazivom Campus Sancti Stephani (Cvitanić, 1991). Ime je dobilo po naslovniku biskupije. Važno je napomenuti da je u 16 st. u prometu vinom s otoka Hvara ostvaren prihod tadašnjih 15.000 dukata godišnje, dok je ukupan iznos trgovine iznosio 70.000 dukata, što upućuje na dobro razvijenu vinogradarsku proizvodnju (Kovačević, 2018:19). U to je vrijeme bilo zabranjeno uvoziti vina s kopna na Hvar jer je vino korišteno za izvoz i kupnju žita koje je bilo nedostatno.

Polje se razvija sve do 19. st., kada je dobilo novi zamah konjunkturom vinarstva jer se hvarska vina tada izvoze u Italiju, Francusku i diljem Mediterana. Sklapanjem vinske klauzule iz 1891.godine i pojavom filoksere stvorena je kriza koja je posljedično potaknula iseljavanje stanovništva s otoka. Početak 20. st. i razdoblje između dva svjetska rata označava nastavak poljoprivredne proizvodnje, ali u nešto manjem obujmu. Kada se govori o udruživanju poljoprivrednih proizvođača, krajem 19. stoljeća počinje osnivanje zadruga s ciljem objedinjenja i distribucije poljoprivrednih proizvoda, prvenstveno eteričnih ulja, kasnije vina, maslinovog ulja i voća (Kovačević, 2018:42).

Poslijeratno razdoblje i socijalističke poljoprivredne reforme uzrokovale su daljnje napuštanje poljoprivredne proizvodnje i prelazak na turizam (Kovačević, 2018:42). U posljednjih tridesetak godina, uslijed razvoja održivog turizma i ekološke proizvodnje, stvorena je prilika za revitalizaciju polja i plasiranje domaćih proizvoda u ponudi novouređenih hvarskih hotela. Polje ostaje nepromijenjeno i u funkciji onoga što je polje kroz čitavu prošlost bilo tzv. ,trbuh otoka“. Takvo ga je UNESCO uvrstio na listu svjetske materijalne baštine 2008. godine (Muzej Staroga Grada, 2020). 


\subsection{Ciljevi i istraživačka pitanja}

Cilj je rada bio analizirati dostupne pokazatelje trenutne poljoprivredne proizvodnje na otoku Hvaru kako bi se izračunala ukupna ekonomska vrijednos svih poljoprivrednih proizvoda i na osnovu tih pokazatelja bi se zaključilo ima li temelja za osnivanje proizvođačke organizacije.

Isto tako idući je cilj bio putem anketnog upitnika ispitati mišljenja OPG-ova u pogledu zainteresiranosti poljoprivrednih proizvođača za korištenjem Agro Huba i međusobnog povezivanja u ODL-u.

Treći cilj je bio definiranje teoretskog modela uspostave ODL-a i Agro Hub-a uz pojašnjenje važnosti udruživanja OPG-a, uspostave robne marke, prikaz sustava pametne poljoprivrede i uspostave geografskog podrijetla za maslinovo ulje i vino.

\section{METODOLOGIJA RADA}

Metode koje su se primjenjivale u istraživanju obuhvaćaju deskriptivnu metodu radi opisivanja značenja i ciljeva poljoprivredne proizvodnje te metodu ankete kojom se provelo istraživanje mišljenja poljoprivrednih proizvođača na otoku Hvaru.

Deskriptivna metoda se sastoji od analize ekonomskih vrijednosti poljoprivredne proizvodnje na otoku Hvaru kako bi se došlo do točnog novčanog iznosa vrijednosti pojedinih proizvoda. Prilikom analize se koristilo izvore Agencije za plaćanje u poljoprivredi, ribarstvu i ruralnom razvoju iz 2019. kao i kataloge kalkulacije poljoprivredne proizvodnje (Hrvatska poljoprivredno-šumarska savjetodavna služba, 2018). Na taj način se dosta precizno odredilo ekonomsku vrijednost pojedinih proizvoda i omogućilo da se izvede zaključak postoji li mogućnost osnivanja proizvođačkih organizacija.

Metodom ankete na prigodnom uzorku provedeno je istraživanje među OPG-ima koji obrađuju parcele u Starogradskom polju, kako bi se dobila slika njihove percepcije poljoprivrednog razvoja Starogradskog polja. Ispitivanje mišljenja proizvođača izvršeno je putem online ankete s zatvorenim i otvorenim tipom pitanja. Anketa (Prilog 1) je bila javno dostupna na mrežnim stranicama Javne ustanove Agencije za zaštitu starogradskog polja u razdoblju od 1. do 20. lipnja 2020. godine i napravljena je od strane autora ovoga rada. Anketu je popunilo 75 poljoprivrednih proizvođača, dobne skupine od 18 do 80 godina. Istraživanje je provedeno u skladu s važećim etičkim normama, odnosno nisu prikupljani nikakvi osjetljivi niti identifikacijski podaci te je u svim predviđenim i obavljenim radnjama slijedilo najaktualnije etičke prakse. Anketu je svatko mogao dobrovoljno ispuniti, pitanja nisu sadržavala nikakve identifikacijske podatke, nisu se prikupljali e-mailovi ili bilo kakvi drugi kontaktni podaci ispitanika tako da $s$ aspekta zaštite podataka provedena anketa nije na nikakav način narušila privatnost ispitanika. Pitanja nisu bila posebno osobne ni osjetljive prirode, odnosno radilo se prije svega o činjeničnim pitanjima vezanima za njihove OPG-ove i njihova mišljenja o razvoju poljoprivrede i OPG-ova na otoku Hvaru. 


\section{REZULTATI RADA}

\subsection{Opis modela „ODL-a i Agro Hub-a“}

ODL otoka Hvara (Slika 3) zamišljen je na principu kratkog opskrbnog lanca (KOL-a). Teorijski, kratki opskrbni lanac podrazumijeva smanjenje broja posrednika u distribuciji robe (najviše 1 posrednik) i proizvoda do krajnjih korisnika uz veći dio dodane vrijednosti za proizvođača (Agrishort, 2018).
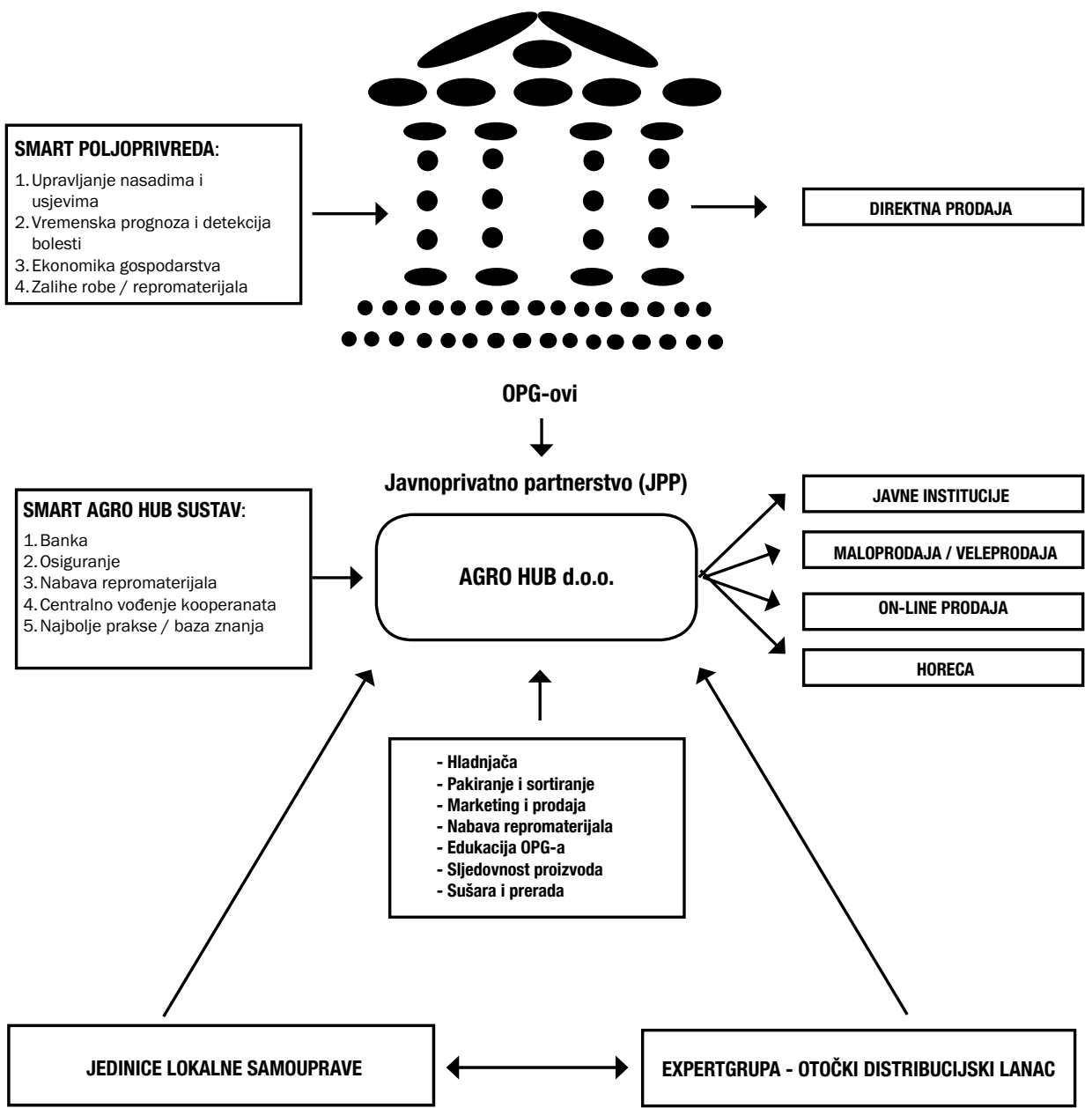

Slika 3. Model "ODL-a s Agro Hub-om" (Izvor: autori)

Što je distribucijski lanac kraći, lakše je za OPG-ove zadržati i isticati autentičnost poljoprivrednih proizvoda. Tako postignuta blizina jedna je od vrlo bitnih značajki kratkih lanaca te su KOL-ovi u tom smislu karakterizirani „kvalitetom“, „transparentnošću“ i „mjestom“ zbog povezanosti između kvalitete i male proizvodnje, tradicionalne prakse, krajobraza, prirode i lokalnih resursa (Conceição Aguiar i sur., 2018). 
Prema Giame Berti i Catherine Mulligan (2016, u: Gajdić, 2019:396) food hubs („prehrambena čvorišta“ ili „prehrambena središta“) se definiraju kao „posrednička organizacija ili tvrtka koja upravlja opskrbnim lancem i pruža logističku i organizacijsku platformu za prikupljanje i distribuciju izvornih poljoprivredno-prehrambenih proizvoda lokalnih i regionalnih proizvođača veleprodajnim kupcima (bolnicama, školama i dr., ustanovama, restoranima, hotelima, itd.) i krajnjim potrošačima (pojedinci i / ili grupe)“.

Predloženi model Agro Hub-a (National Agricultural Library, 2020) predstavlja organizacijsku platformu hvarskih poljoprivrednih proizvođača koji bi im omogućio otkup robe, skladištenje, sortiranje, pakiranje i daljnju distribuciju prema krajnjim korisnicima. OPG-ovi koji bi koristili Agro Hub formirali bi poljoprivrednu zadrugu, a Agro Hub bi pružao uslugu skladištenja, pakiranja i distribucije njihovih proizvoda. Isto tako, da bi se u narednim fazama formirala proizvođačka organizacija na otoku Hvaru, mora biti zadovoljen glavni preduvjet od $3.000 .000 \mathrm{kn}$ prodanih proizvoda, stoga je osnivanje Agro Hub-a i proizvođačke organizacije od posebne važnosti za otok Hvar.

Očekivani rezultati implementacije novog modela „ODL-a i Agro Hub-a“ kao logističko-distribucijskog centra su: poboljšanje rezultata poslovanja i udruživanje otočnih OPG-ova, povećanje prepoznatljivosti otočnih poljoprivrednih proizvoda kroz zajedničku tržnu marku te viša razina integriranosti poljoprivrede s sustavima pametne poljoprivrede koji će doprinijeti višoj razini konkurentnosti poljoprivrednih proizvoda na otočkom tržištu.

\subsection{Ekonomska vrijednost poljoprivredne proizvodnje na otoku Hvaru}

Tablica 1. Broj OPG-ova, poljoprivredne površine i broj parcela na otoku Hvaru

\begin{tabular}{|l|c|c|c|}
\hline \multicolumn{1}{|c|}{ JLS } & Broj OPG-a & Korištene polj. površine & Broj parcela \\
\hline Stari Grad & 453 & $447,59 \mathrm{ha}$ & 2.589 \\
\hline Hvar & 294 & $337,01 \mathrm{ha}$ & 3.605 \\
\hline Jelsa & 651 & $627,59 \mathrm{ha}$ & 5.200 \\
\hline Sućuraj & 103 & $129,39 \mathrm{ha}$ & 566 \\
\hline Ukupno & $\mathbf{1 . 5 0 1}$ & $\mathbf{1 . 5 4 1 , 5 8}$ ha & $\mathbf{1 1 . 9 6 0}$ \\
\hline
\end{tabular}

Izvor podataka: Državni zavod za statistiku RH $2003^{2}$ (Izračun autora)

Iz priložene Tablice 1 može se zaključiti da je glavna karakteristika otočne poljoprivrede veliki broj sitnih parcela, te da na jedan OPG prosječno otpada oko 8 parcela veličine oko 1 ha, što je značajna prepreka za intenzivniju proizvodnju. $S$ obzirom na sve probleme koji utječu na otočku poljoprivredu nužno je zajedničko djelovanje svih jedinica lokalne samouprave kako bi donijeli konkretne i učinkovite poljoprivredne mjere. U nastavku rada bit će analizirane ekonomske vrijednosti poljoprivredne proizvodnje po sektorima kako bi se stekli uvidi u količinu poljoprivredne proizvodnje.

2 Posljednji cjelovit i samostalan popis poljoprivrede proveden je na teritoriju Republike Hrvatske od 1. do 15. lipnja 2003. Tijekom 2021. proveden je zadnji popis poljoprivrede međutim rezultati nisu bili dostupni u vrijeme pisanja ovoga rada. 
Tablica 2. Proizvodnja maslina (maslinovog ulja) na otoku Hvaru

\begin{tabular}{|l|c|}
\hline Poljoprivredno područje (ha) Hvar & $691,28 \mathrm{ha}(8 \%$ udjela u RH) \\
\hline Poljoprivredno područje (ha) RH & $8.315 \mathrm{ha}$ \\
\hline Prinos po hektaru (kg) & $6.100 \mathrm{~kg}$ \\
\hline Ukupna proizvodnja (kg-t) & $5.216 .808 \mathrm{~kg} \mathrm{ili} 4.217 \mathrm{t}$ \\
\hline Broj proizvođača na Hvaru & $866(8 \%$ udjela u RH) \\
\hline Broj proizvođača u RH & (iskoristivost $11 \%) 519.5091$ \\
\hline \multirow{3}{*}{ Ukupna proizvodnja maslinovog ulja (l) } & (iskoristivost $15 \%) 708.4581$ \\
\cline { 2 - 2 } & (iskoristivost $18 \%) 850.1081$ \\
\cline { 2 - 2 } Prosječna proizvedena količina (l) & 692.6911 \\
\hline Cijena (prosjek) & $60 \mathrm{kn}$ \\
\hline \multirow{2}{*}{ Ukupna ekonomska vrijednost (kn-\$) } & $41.561 .460 \mathrm{kn}$ \\
\cline { 2 - 2 } & $6.679 .550 \$$ \\
\hline
\end{tabular}

Izvor: Agencija za plaćanja u poljoprivredi, ribarstvu i ruralnom razvoju, 2019; Hrvatska poljoprivredno-šumarska savjetodavna služba, 2018

Cilj je priložene Tablice 2 utvrditi ekonomsku vrijednost poljoprivredne proizvodnje maslina i maslinovog ulja na otoku Hvaru. Korišteni su izvori Agencije za plaćanje u poljoprivredi, ribarstvu i ruralnom razvoju iz 2019., kao i kataloga kalkulacije poljoprivredne proizvodnje Hrvatske poljoprivredno-šumarske savjetodavne službe iz 2018. Cijene i prinos po hektaru umanjeni su zbog ograničenih otočkih uvjeta. Bitno je napomenuti da navedeni rezultati mogu oscilirati jer korištene kalkulacije možda ne izražavaju realno stanje na terenu. Navedene kalkulacije koriste da bi se ugrubo procijenila mogućnost osnivanja proizvođačkih organizacija u maslinarstvu, kao i mogući promet robe kroz Agro Hub.

Tablica 3. Proizvodnja grožda i vina na otoku Hvaru

\begin{tabular}{|l|c|}
\hline Poljoprivredna površina (ha) Hvar & 335,24 ha (6\% udjela) \\
\hline Poljoprivredna površina (ha) Republika Hrvatska & $5.950 \mathrm{ha}$ \\
\hline Prinos po hektaru (kg/ha) & $9.000 \mathrm{~kg} / \mathrm{ha}$ \\
\hline Ukupna proizvodnja (kg-t) & $3.000 .000 \mathrm{~kg}$ ili $3.000 \mathrm{t}$ \\
\hline Broj proizvođača - Hvar & $413(4 \%$ udjela) \\
\hline Broj proizvođača u RH & 10.477 \\
\hline Ukupna proizvodnja vina (l) & $30 \mathrm{kn} / \mathrm{l}$ \\
\hline Cijena (prosječna) & $49.500 .000 \mathrm{kn}$ \\
\hline \multirow{2}{*}{ Ukupna ekonomska vrijednost $(\mathrm{kn}-\$)$} & $7.966 .139 \$$ \\
\cline { 2 - 2 }
\end{tabular}

Izvor podataka: Agencija za plaćanja u poljoprivredi, ribarstvu i ruralnom razvoju, 2019; Hrvatska poljoprivrednošumarska savjetodavna služba, 2018 
Cilj je priložene Tablice 3 utvrditi ekonomsku vrijednost poljoprivredne proizvodnje vinove loze i vina na otoku Hvaru. Korišteni su izvori Agencije za plaćanje u poljoprivredi, ribarstvu i ruralnom razvoju iz 2019. i kataloga kalkulacije poljoprivredne proizvodnje Hrvatske poljoprivredno-šumarske savjetodavne službe iz 2018. Cijene i prinos po hektaru umanjeni su zbog ograničenih otočkih uvjeta. Bitno je napomenuti da navedeni rezultati mogu oscilirati jer korištene kalkulacije možda ne izražavaju realno stanje na terenu. Navedene kalkulacije koriste da bi se ugrubo procijenila mogućnost osnivanja proizvođačkih organizacija u vinogradarstvu, kao i mogući promet robe kroz Agro Hub.

Tablica 4. Proizvodnje lavandinog ulja na otoku Hvaru

\begin{tabular}{|l|c|}
\hline Poljoprivredna površina (ha) Hvar & 67,27 ha (34\% udjela) \\
\hline Poljoprivredna površina (ha) Republika Hrvatska & $196 \mathrm{ha}$ \\
\hline Prinos po hektaru (l/ha) & $83 \mathrm{l} / \mathrm{ha}$ \\
\hline Ukupna proizvodnja (l-t) & $5.561 \mathrm{lili} 5 \mathrm{t}$ \\
\hline Broj proizvođača na Hvaru & $126(40 \%$ udjela) \\
\hline Broj proizvođača Republike Hrvatske & 318 \\
\hline Cijena (prosječna) & $350 \mathrm{kn}$ \\
\hline \multirow{2}{*}{ Ukupna ekonomska vrijednost (kn-\$) } & $1.954 .050 \mathrm{kn}$ \\
\cline { 2 - 2 } & $309.368 \$$ \\
\hline
\end{tabular}

Izvor: Agencija za plaćanja u poljoprivredi, ribarstvu i ruralnom razvoju, 2019; Hrvatska poljoprivredno-šumarska savjetodavna služba, 2018

Cilj je priložene Tablice 4 je utvrditi ekonomsku vrijednost poljoprivredne proizvodnje lavande na otoku Hvaru. Korišteni su izvori Agencije za plaćanje u poljoprivredi, ribarstvu i ruralnom razvoju iz 2019. i kataloga kalkulacije poljoprivredne proizvodnje Hrvatske poljoprivredno-šumarske savjetodavne službe iz 2018. Cijene i prinos po hektaru umanjeni su zbog ograničenih otočkih uvjeta. Bitno je napomenuti da navedeni rezultati mogu oscilirati jer korištene kalkulacije možda ne izražavaju realno stanje na terenu. Navedene kalkulacije koriste da bi se ugrubo procijenila mogućnost osnivanja proizvođačkih organizacija u proizvodnji lavande, kao i mogući promet robe kroz Agro Hub.

Tablica 5. Proizvodnje voća na otoku Hvaru

\begin{tabular}{|l|c|c|c|c|c|c|}
\hline \multicolumn{1}{|c|}{ Voće } & $\begin{array}{c}\text { Poljoprivredna } \\
\text { površina (ha) }\end{array}$ & $\begin{array}{c}\text { Prinos po } \\
\text { hektaru } \\
(\mathbf{k g} / \mathbf{h a})\end{array}$ & $\begin{array}{c}\text { Ukupna } \\
\text { proizvodnja } \\
(\mathbf{k g})\end{array}$ & $\begin{array}{c}\text { Cijena } \\
(\mathbf{k n})\end{array}$ & $\begin{array}{c}\text { Ukupna } \\
\text { ekonomska } \\
\text { vrijednost } \\
(\mathbf{k n})\end{array}$ & $\begin{array}{c}\text { Broj } \\
\text { proizvodača }\end{array}$ \\
\hline Badem & 0,88 & 6,600 & 5,808 & 30 & 174.240 & 6 \\
\hline Breskva & 0,92 & 20.000 & 18.400 & 4 & 73.600 & 8 \\
\hline Kruška & 0,21 & 20.000 & 4.200 & 4 & 16.800 & 1 \\
\hline
\end{tabular}




\begin{tabular}{|l|c|c|c|c|c|c|}
\hline Limun & 0,73 & 30.000 & 21.900 & 10 & 219.000 & 4 \\
\hline Mandarina & 0,24 & 30.000 & 7.920 & 2 & 15.840 & 3 \\
\hline Naranča & 0,08 & 30.000 & 2.400 & 7 & 16.800 & 1 \\
\hline Smokva & 3,17 & 11.600 & 36.772 & 10 & 367.720 & 14 \\
\hline Trešnja & 0,29 & 10.000 & 2.900 & 13.5 & 39.150 & 3 \\
\hline Višnja & 0,1 & 10.000 & 1.000 & 4.5 & 4.500 & 2 \\
\hline $\begin{array}{l}\text { Miješano } \\
\text { voće }\end{array}$ & 5,82 & - & - & - & - & 44 \\
\hline Ukupno & $\mathbf{1 1 , 3 9}$ & - & $\mathbf{1 0 1 . 3 0 0}$ & - & $\mathbf{9 2 7 . 6 5 0}$ & $\mathbf{7 6}$ \\
\hline
\end{tabular}

Izvor podataka: Agencija za plaćanja u poljoprivredi, ribarstvu i ruralnom razvoju, 2019; Hrvatska poljoprivrednošumarska savjetodavna služba, 2018

Cilj je priložene Tablice 5 utvrditi ekonomsku vrijednost poljoprivredne proizvodnje voća na otoku Hvaru. Korišteni su izvori Agencije za plaćanje u poljoprivredi, ribarstvu i ruralnom razvoju iz 2019. i kataloga kalkulacije poljoprivredne proizvodnje Hrvatske poljoprivredno-šumarske savjetodavne službe iz 2018. Cijene i prinos po hektaru umanjeni su zbog ograničenih otočkih uvjeta. Bitno je napomenuti da navedeni rezultati mogu oscilirati jer korištene kalkulacije možda ne izražavaju realno stanje na terenu. Navedene kalkulacije koriste da bi se ugrubo procijenila mogućnost osnivanja proizvođačkih organizacija u voćarstvu, kao i mogući promet robe kroz Agro Hub.

Tablica 6. Proizvodnje povrća na otoku Hvaru

\begin{tabular}{|l|c|c|c|c|c|c|}
\hline Povrće & $\begin{array}{c}\text { Poljoprivredna } \\
\text { površina (ha) }\end{array}$ & $\begin{array}{c}\text { Prinos po } \\
\text { hektaru (kg/ } \\
\text { ha) }\end{array}$ & $\begin{array}{c}\text { Ukupna } \\
\text { proizvodnja } \\
(\mathbf{k g})\end{array}$ & $\begin{array}{c}\text { Cijena } \\
(\mathbf{k n})\end{array}$ & $\begin{array}{c}\text { Ukupna } \\
\text { ekonomska } \\
\text { vrijednost } \\
(\mathbf{k n})\end{array}$ & $\begin{array}{c}\text { Broj } \\
\text { proizvođača }\end{array}$ \\
\hline Češnjak & 0,04 & 5.000 & 200 & 9 & 1.800 & 1 \\
\hline Krumpir & 5,09 & 30.000 & 152.700 & 1.4 & 213.780 & 27 \\
\hline Luk & 0,34 & 35.000 & 11.900 & 1.4 & 16.660 & 3 \\
\hline Rajčica & 0,13 & 60.000 & 7.800 & 2 & 15.600 & 2 \\
\hline Tikvice & 0,09 & 12.000 & 1.080 & 4 & 4.320 & 1 \\
\hline $\begin{array}{l}\text { Miješano } \\
\text { povrće }\end{array}$ & 21,45 & - & - & - & - & 149 \\
\hline Ukupno & $\mathbf{2 7 , 1 4}$ & - & $\mathbf{1 7 3 . 6 8 0}$ & - & $\mathbf{2 5 2 . 1 6 0}$ & $\mathbf{1 8 3}$ \\
\hline
\end{tabular}

Izvor podataka: Agencija za plaćanja u poljoprivredi, ribarstvu i ruralnom razvoju, 2019; Hrvatska poljoprivrednošumarska savjetodavna služba, 2018

Cilj je priložene Tablice 6 utvrditi ekonomsku vrijednost poljoprivredne proizvodnje povrća na otoku Hvaru. Korišteni su izvori Agencije za plaćanje u poljoprivredi, ribarstvu i ruralnom razvoju iz 2019. i kataloga kalkulacije poljoprivredne proizvodnje Hrvatske poljoprivredno-šumarske savjetodavne službe iz 2018. Cijene i prinos po hek- 
taru umanjeni su zbog ograničenih otočkih uvjeta. Bitno je napomenuti da navedeni rezultati mogu oscilirati jer korištene kalkulacije možda ne izražavaju realno stanje na terenu. Navedene kalkulacije koriste da bi se ugrubo procijenila mogućnost osnivanja proizvođačkih organizacija u povrćarstvu, kao i mogući promet robe kroz Agro Hub.

\subsection{Anketni upitnik}

Iako ne postoje službeni izvori o broju OPG-ova koji obrađuju površine na prostoru Starogradskog polja, po slobodnoj interpretaciji autora taj je broj oko 350, tako da anketa obuhvaća oko $21 \%$ proizvođača. Polazište ankete je dobivanjemišljenja javnosti, odnosno poljoprivrednih proizvođača o zainteresiranosti za uspostavu novog tržnog lanca te o postojećem stanju poljoprivrede u Starogradskom polju.

$\mathrm{Na}$ upit kako ocjenjuju postojeću razinu poljoprivrednog razvoja Starogradskog polja, ispitanici su odgovorili u sljedećim omjerima:

Tablica 7. Ocjena poljoprivrednog razvoja Starogradskog polja po spolu (\%)

\begin{tabular}{|l|c|c|}
\hline \multicolumn{1}{|c|}{ Spol } & N & $\%$ \\
\hline Muškarci & 54 & $72 \%$ \\
\hline Žene & 21 & $28 \%$ \\
\hline
\end{tabular}

Većina ispitanika je muškog spola, odnosno $72 \%$ dok je ženskog spola $28 \%$.

Tablica 8. Ocjena poljoprivrednog razvoja Starogradskog polja po dobi (\%)

\begin{tabular}{|l|c|c|}
\hline \multicolumn{1}{|c|}{ Dob } & N & $\%$ \\
\hline Ispod 20 godina & 1 & $1,13 \%$ \\
\hline Od 21 do 30 & 7 & $9,3 \%$ \\
\hline Od 31 do 40 & 27 & $36 \%$ \\
\hline Od 41 do 50 & 14 & $18,7 \%$ \\
\hline Iznad 50 & 26 & $34,7 \%$ \\
\hline
\end{tabular}

Po pitanju dobi, najviše ispitanika je između 31 i 40 godina i to $36 \%$, zatim iznad 50 godina $34,7 \%$ dok je najmanji broj ispitanika ispod 20 godina i to $1,13 \%$.

Tablica 9. Glavni proizvod / usluga ispitanih OPG-ova

\begin{tabular}{|l|c|}
\hline Molimo navedite koji je glavni proizvod / usluga Vašeg OPG-a? & N \\
\hline Voće & 11 \\
\hline Povrće & 19 \\
\hline Masline & 58 \\
\hline Lavanda & 9 \\
\hline Vinova loza & 40 \\
\hline Smilje & 1 \\
\hline Aromatično bilje & 1 \\
\hline Sadnice & 1 \\
\hline Stočarstvo & 1 \\
\hline
\end{tabular}


Iz ovoga pitanja se može zaključiti kako su masline, vinova loza i povrće najčešće uzgajana kultura.

Tablica 10. Primarni kupci proizvoda / usluga

\begin{tabular}{|l|c|}
\hline Primarni kupci Vaših proizvoda / usluga su: & N \\
\hline Pojedinačni potrošači & 54 \\
\hline Trgovački lanci, trgovine & 2 \\
\hline Horeca & 9 \\
\hline Osobna potrošnja & 41 \\
\hline
\end{tabular}

U pogledu prodaje domaćih proizvoda najveći broj ispitanika svoje proizvode prodaje pojedinačnim potrošačima i koristi za osobnu potrošnju. Neznatan broj prodaje trgovačkim lancima i hotelskim kućama.

Tablica 11. Članstvo klastera / proizvođacke organizacije / udruge / zadruge

\begin{tabular}{|l|c|c|}
\hline $\begin{array}{l}\text { Je li Vaše gospodarstvo član nekog klastera / } \\
\text { proizvođačke organizacije / udruge / zadruge? }\end{array}$ & $\mathbf{N}$ & $\%$ \\
\hline $\mathrm{Da}$ & 8 & $10,7 \%$ \\
\hline $\mathrm{Ne}$ & 67 & $89,3 \%$ \\
\hline
\end{tabular}

Gotovo 90\% ispitanika nije član nikakvog udruženja dok oko $10 \%$ je član udruženja / zadruge.

Tablica 12. Problemi i prepreke u poslovanju OPG-a

\begin{tabular}{|l|c|}
\hline $\begin{array}{l}\text { Koji su najčešći problemi i prepreke s kojima se susrećete u Vašem } \\
\text { poslovanju, a specifični su za djelatnost koju obavljate? }\end{array}$ & N \\
\hline Slaba poslovna povezanost gospodarstava u sektoru & 20 \\
\hline Nerazvijena mreža otkupljivača i distribucije & 42 \\
\hline Niske prodajne cijene & 29 \\
\hline Visoke cijene inputa / repromaterijala za proizvodnju & 21 \\
\hline Nemogućnost ili kašnjenje u naplati za izdane robe / usluge & 10 \\
\hline Ograničen pristup sredstvima za financiranje i investiranje & 12 \\
\hline Nedostupnost informacija o mogućnostima potpora i sufinanciranja & 23 \\
\hline $\begin{array}{l}\text { Nedostatak stručnih specifičnih znanja za praćenje suvremene tehnologije } \\
\text { proizvodnje }\end{array}$ & 15 \\
\hline Nedovoljno raspoloživa sezonska radna snaga & 6 \\
\hline Ograničene mogućnosti okrupnjavanja zemljišta & 14 \\
\hline
\end{tabular}


Kao najveće probleme sa kojima se ispitanici susreću navedeni su nerazvijena mreža otkupljivača i distribucije proizvoda, niske prodajne cijene, nedostupnost informacija po pitanju potpora i sufinanciranja proizvodnje i visoke cijene inputa.

Tablica 13. Edukacija / trening OPG-a

\begin{tabular}{|l|c|c|}
\hline $\begin{array}{l}\text { Jeste li zainteresirani za treninge / edukacije / } \\
\text { obuke, a da su u svrhu unapređenja poslovanja } \\
\text { OPG-a? }\end{array}$ & N & $\%$ \\
\hline $\mathrm{Da}$ & 58 & $77,3 \%$ \\
\hline $\mathrm{Ne}$ & 17 & $22,7 \%$ \\
\hline
\end{tabular}

Oko $77 \%$ ispitanika je zainteresirano za neki vid edukacije kako bi unaprijedili poslovanje svojih OPG-a.

Tablica 14. Unapredenje poslovanja OPG-a unutar ODL-a

\begin{tabular}{|l|c|c|}
\hline $\begin{array}{l}\text { Planirate li nova ulaganja unutar OPG-a ako se } \\
\text { postavi novi distributivni lanac poljoprivredne } \\
\text { proizvodnje? }\end{array}$ & N & $\%$ \\
\hline $\mathrm{Da}$ & 57 & $76 \%$ \\
\hline $\mathrm{Ne}$ & 18 & $24 \%$ \\
\hline
\end{tabular}

Ukupno 76\% ispitanika povećalo bi svoja ulaganja u OPG-e ukoliko bi se postavio novi distributivni lanac poljoprivredne proizvodnje, $24 \%$ ispitanika nije zainteresirano za povećanje ulaganja.

Tablica 15. Distribucijski centar kao pokretač OPG-a

\begin{tabular}{|l|c|c|}
\hline $\begin{array}{l}\text { Po Vašem mišljenju, koliko bi uspostava } \\
\text { otkupnog distribucijskog centra s mogućom } \\
\text { doradom proizvoda na principu zadrugarstva } \\
\text { unaprijedila razvoj Vašeg OPG-a? }\end{array}$ & N & $\%$ \\
\hline Nikako & 9 & $10,6 \%$ \\
\hline U znatnoj mjeri & 44 & $58,7 \%$ \\
\hline Od presudne važnosti & 23 & $30,7 \%$ \\
\hline
\end{tabular}

Najveći broj ispitanika oko 60\% smatra da bi distribucijski centar u znatnoj mjeri unaprijedio njihov rada, a oko $30 \%$ ispitanika smatra da bi im to bilo od presudne važnosti. Tek oko $10 \%$ smatra da im to nije od važnosti. Dobiveni rezultati u ovome pitanju uveliko pokazuju opravdanost daljnjeg rada na uspostavi 
ODL-a i Agro Huba jer i ovaj relativno mali uzorak pokazuje veliku važnost poljoprivredne infrastrukture u razvoju određenog područja u ovom slučaju otoka Hvara.

Tablica 16. Korištenje distribucijskog centra

\begin{tabular}{|l|c|c|}
\hline $\begin{array}{l}\text { Biste li koristili usluge distribucijskog } \\
\text { centra kada bi bio osnovan? }\end{array}$ & N & $\%$ \\
\hline $\mathrm{Da}$ & 71 & $94,7 \%$ \\
\hline $\mathrm{Ne}$ & 4 & $5,3 \%$ \\
\hline
\end{tabular}

Isto tako jako važno pitanje o korištenju distribucijskog centra gdje bi gotovo 95\% ispitanika koristilo njegove usluge ukoliko bi se osnovao, tek neznatan broj nije zainteresiran za ovakav vid poslovanja.

Tablica 17. Brendiranje proizvoda

\begin{tabular}{|l|c|c|}
\hline $\begin{array}{l}\text { Smatrate li da treba brendirati proizvode } \\
\text { Starogradskog polja pod jednom } \\
\text { prepoznatljivom robnom markom? }\end{array}$ & N & $\%$ \\
\hline $\mathrm{Da}$ & 71 & $94,7 \%$ \\
\hline $\mathrm{Ne}$ & 4 & $5,3 \%$ \\
\hline
\end{tabular}

Kao i kod prethodnog pitanja skoro 95\% ispitanika je za brendiranje hvarskih proizvoda kako bi kroz jednu tržnu marku lakše mogli plasirati ulje,vino, lavandino ulje, voće i povrće. Oko 5\% se ne slaže sa važnosti brendiranja proizvoda.

Tablica 18. Geografsko podrijetlo vina i maslinovog ulja

\begin{tabular}{|l|c|c|}
\hline $\begin{array}{l}\text { Jeste li za traženje geografskog porijekla } \\
\text { za maslinovo ulje i vino sa područja otoka } \\
\text { Hvara? }\end{array}$ & N & $\%$ \\
\hline $\mathrm{Da}$ & 71 & $94,7 \%$ \\
\hline $\mathrm{Ne}$ & 4 & $5,3 \%$ \\
\hline
\end{tabular}

I za ovo pitanje identični odgovori kao u posljednja dva pitanja. Oko $95 \%$ ispitanika smatra kako je nužno tražiti geografsko porijeklo za vino i maslinovo ulje kako bi ti proizvodi našli lakši put u promociji i krajnjoj prodaji. Svega $5 \%$ se ne slaže sa ovom tvrdnjom.

Kao zaključak dobivenih rezultata provedene ankete, s napomenom da se radi o prigodnom uzorku, može se zaključiti kako je prosječan nositelj OPG-a na otoku Hvaru muškarac, u dobi od 31 do 40 godina. Pretežno uzgaja masline, vinovu lozu i povrće. 
Proizvode plasira pojedinačnim kupcima i za osobnu upotrebu, nije član zadruge / proizvođačke organizacije. Najveći problemi sa kojima se susreće: nedostatak organiziranog otkupa, niske cijene proizvoda, ne postojanje adekvatnih informacija oko potencijalnih fondova i investicija u poljoprivredi i visoke cijene inputa / repromaterijala. Zainteresiran je za dodatnu edukaciju i smatra kako bi osnivanje ODL-a i Agro Huba uvelike poboljšalo njegovu proizvodnju. Ako bi se osnovao ODL i Agro Hub koristio bi njegove usluge, povećao proizvodnju a $\mathrm{u}$ isto vrijeme smatra da brendiranje proizvoda i geografsko porjeklo za vino i maslinovo ulje mogu uvelike pomoći za što bolji plasman njegovih proizvoda.

\section{DISKUSIJA}

Rezultati deskriptivnog istraživanja i provedene ankete pokazuju stanoviti potencijal poljoprivredne proizvodnje na otoku Hvaru. Ukupna poljoprivredna površina iznosi 1.134,32 ha, a najznačajnije kulture su maslina, vinova loza, lavanda i u manjim količinama voće i povrće s ukupnom ekonomskom vrijednosti od 97.034.767,06 kn (Tablica 19).

Postojeću poljoprivredu karakterizira nekoliko ključnih problema:

- nedostatak neophodnih suvremenih tehnologija u proizvodnji, preradi te plasmanu poljoprivrednih proizvoda;

- nedostatak poduzetničkih ideja i inicijativa povezanih s plasmanom te stvaranjem dodane vrijednosti otočnih poljoprivrednih proizvoda (nedostatak robnih marki otočnih poljoprivrednih proizvoda, nepovezanost OPG-ova te neorganiziranost lokalnog tržišsta);

- nedovoljna uključenost otočke poljoprivrede te poljoprivrednih proizvoda s ostalim djelatnostima na otoku, prvenstveno s turizmom (nepovezanost poljoprivrednih i ugostiteljskih subjekta);

- nedovoljna edukacija OPG-ova; i

- nepostojanje udruženja OPG-ova, zadruga i proizvođačkih organizacija i sl. (Lokalna akcijska grupa Brač, 2014).

Tablica 19. Ukupna ekonomska vrijednost, poljoprivredne površine i broj proizvođača otoka Hvara

\begin{tabular}{|l|c|c|c|}
\hline \multicolumn{1}{|c|}{ Usjevi / biljke } & $\begin{array}{c}\text { Poljoprivredna } \\
\text { površina (ha) }\end{array}$ & $\begin{array}{c}\text { Ukupna ekonomska } \\
\text { vrijednost (\$) }\end{array}$ & Broj proizvođača \\
\hline Maslina (ulje) & 691,28 & $6.679 .550 \$$ & 566 \\
\hline Vinova loza & 335,24 & 7.966 .139 & 413 \\
\hline Lavanda (ulje) & 67,27 & 309.368 & 126 \\
\hline Voće & 11,39 & 149.284 & 76 \\
\hline Povrće & 27,14 & 40.540 & 183 \\
\hline Ukupno & $\mathbf{1 . 1 3 4 , 3 2}$ & $\mathbf{1 5 . 1 4 4 . 8 8 1}$ & $\mathbf{1 . 3 6 4}$ \\
\hline
\end{tabular}

Izvor podataka: Agencija za plaćanja u poljoprivredi, ribarstvu i ruralnom razvoju, 2019 
Uzgojem maslina bavi se 566 OPG-ova na otoku Hvaru, što iznosi 8\% ukupnih proizvođača u RH (Tablica 2) na površini od 691,28 ha, što je $8 \%$ u odnosu na površine pod maslinama u RH. Ekonomska vrijednost proizvedenog maslinovog ulja iznosi $41.561 .460 \mathrm{kn}$ (Tablica 2). Na osnovi prikazanih podataka može se zaključiti da maslinarstvo predstavlja, uz uzgoj vinove loze, najvažniju gospodarsku granu na otoku Hvaru i daljnja bi se ulaganja u maslinarstvo višestruko isplatila. Pogodnu klimu, tradiciju uzgoja i isplativost nužno je dalje nadograditi povećanjem plasmana maslinovog ulja. Trenutno ne postoje otkupni centri za ulje, već proizvođači plasiraju svoje proizvode individualnim potrošačima, što predstavlja veliki problem za većinu OPG-ova koji nemaju prodajne kanale.

Vinova loza uzgaja se na površini od 335,24 ha, što je $6 \%$ ukupnih površina u RH, a 413 OPG-ova se bavi uzgojem vinove loze, što predstavlja 4\% ukupnih OPG-ova u RH koji se bave uzgojem vinove loze (Tablica 3). Vinova loza uz maslinu predstavlja najvažniju gospodarsku granu i ekonomska vrijednost proizvodnje vina iznosi $49.500 .000 \mathrm{kn}$ (Tablica 3).

Lavanda je prepoznatljiva poljoprivredna kultura otoka Hvara. OPG-ovi (126) s otoka Hvara koji se bave uzgojem lavande predstavljaju $40 \%$ proizvođača u $\mathrm{RH}$, dok površine pod lavandom predstavljaju 34\% ukupnih površina RH. Ukupna ekonomska vrijednost proizvedenog ulja iznosi $1.954 .050 \mathrm{kn}$ (Tablica 4).

Proizvodnja voća i povrća, u usporedbi s prethodno navedenim kulturama, nije razvijena. Ukupna ekonomska vrijednost proizvedenog povrća iznosi $252.160 \mathrm{kn}$, a uzgaja se na površini od 27,14 ha (Tablica 5), dok se voće uzgaja na površinama od 11,39 ha i ekonomska vrijednost proizvedenog voća iznosi $927.650 \mathrm{kn}$. Nedostatak ove kalkulacije odnosi se na miješane forme uzgoja koje se ne mogu ekonomski procijeniti te se može zaključiti da je proizvodnja voća i povrća veća od prikazanih vrijednosti.

Kada je riječ o plasmanu proizvoda, anketa je pokazala da poljoprivredni proizvođači njih 54 - najviše svojih proizvoda plasiraju individualnim kupcima, dok 41 uzgaja za svoje potrebe. Broj proizvođača koji plasiraju svoje proizvode trgovačkim lancima i hotelskim kućama je zanemariv (Tablica 10). Temeljem ovih odgovora može se zaključiti kako ne postoji distribucijski lanac prodaje proizvoda. Prodavači se baziraju isključivo na osobne mreže kontakata, a izostaje organizirani plasman proizvoda. Republika je Hrvatska putem Akcijskog plana promoviranja i jačanja kratkih lanaca u opskrbi hranom ustanova iz javnog sektora za razdoblje 2019. i 2020. godine (Vlada RH, 2019). kao i financijskim mjerama kojima to potiču, omogućila razvoj KOL-ova, dok se posebna pogodnost očituje kroz $\mathrm{Za}$ kon o javnoj nabavi (NN 120/16). U njemu je naznačeno da uz cijene naručitelj treba uzeti u obzir kriterije kojima se vrednuju proizvodi načinjeni u sustavima kvalitete poljoprivrednih i prehrambenih proizvoda. Na taj se način potiče OPG-ove da se kroz udruživanja i formiranja KOL-ova uključe u „zelenu javnu nabavu“, putem koje imaju mogućnost plasirati svoje proizvode prema medicinskim i obrazovnim ustanovama koje predstavljaju veliko tržište. Razvoj i uspostava ODL-ova uvelike bi unaprijedili poljoprivrednu proizvodnju, kao i plasman kvalitetnih poljoprivrednih proizvoda na lokalno otočko tržište. 
Zadrugarstvo i drugi oblici povezivanja na otoku Hvaru nerazvijeni su i ne postoje „proizvođačke organizacije“. Od 75 anketiranih proizvođača samo je 8 ispitanika član nekog udruženja. Treba napomenuti da zadrugarstvo koje je bilo aktivno prije 1990. godine ima i pozitivne značajke razvoja poljoprivrede na otoku. Zadruge su bile povezane $s$ velikim prerađivačkim centrima (npr. Dalmacijavino i Badel) koji su otkupljivali sve proizvedene količine prvenstveno vinove loze, a zauzvrat osiguravale redovne isplate $\mathrm{i}$ nabavku repromaterijala za kooperante. Stoga je nužno realno procijeniti značaj zadrugarstva i na adekvatan način poboljšati njegovo djelovanje u skladu s trenutnim tržišnim poslovanjem. Može se zaključiti da povezivanje OPG-ova s jasnim pravilima poslovanja može doprinijeti razvoju otočke poljoprivrede. OPG-ovi koji dominiraju proizvodnom strukturom na otoku Hvaru uglavnom sudjeluju u kratkim lancima vrijednosti koji obično završavaju za osobnu upotrebu, a manji dio na lokalnim zelenim tržištima. Međusobno povezivanje OPG-ova omogućava da veći dio novostvorene dodatne vrijednosti proizvoda ostane proizvođaču (Borzaga i Galera, 2012)., umjesto da se kroz opskrbni lanac, preko velikog broja sudionika u procesu distribucije, prelije izvan lokalnog gospodarstva. Isto tako, formiranje poljoprivredne zadruge i Agro Hub-a preduvjet je za formiranje proizvođačkih organizacija (Ministarstvo poljoprivrede RH, 2020).

Najbolji je hrvatski primjer uspješnog modela Distributivni centar za voće i povrće d.o.o. iz Velike Gorice: „Da bi se dobio status proizvođačke organizacije, mora biti ispunjeno niz preduvjeta. Uz ukupni godišnji promet veći od 5 milijuna kuna, jedan od važnijih je postojanje odgovarajuće infrastrukture za prihvat, skladištenje, certificiranje, pakiranje i distribuciju voća i povrća. Ovaj su uvjet članovi Zadruge ispunili kroz Distributivni centar za voće i povrće d.o.o., koji su 2008. godine osnovali Zagrebačka županija, Grad Velika Gorica i Zadruga 'Zagrebački voćnjaci'. Distributivni centar je svojevrsni outsourcing PZ 'Zagrebački voćnjaci'. On zadrugarima pruža uslugu skladištenja, pakiranja i distribucije njihovih proizvoda" (Distributivni centar za voće i povrće d.o.o., 2020).

Glavna se razlika između ova dva modela odnosi na kapacitet i logistiku distribucije, odnosno blizinu većeg tržišta. Može se zaključiti da je primjer Distributivnog centra za voće i povrće d.o.o. ogledni primjer kako bi trebao izgledati hvarski model razvoja poljoprivredne proizvodnje, kao i način plasmana proizvoda.

Kroz anketu se utvrdilo koji su najveći problemi hvarske poljoprivrede. Iako se u anketi moglo ponuditi više odgovora, najveći je problem nerazvijena mreža kupaca i distribucija, zatim slijedi niska cijena proizvoda, nepostojanje adekvatnih informacija u vezi s raspoloživim sredstvima u poljoprivredi i visoka cijena repromaterijala (Tablica 12). Poljoprivredni proizvođači prepoznali su i izrazili potrebu za dodatnom edukacijom. Od ukupnog broja ispitanika 58 ih je odgovorilo pozitivno na pitanje zainteresiranosti za stjecanje znanja (Tablica 13). S obzirom na stalno poboljšanje i razvoj novih znanja u poljoprivredi uz klasično osposobljavanje otvara se potreba za implementaciju „pametne poljoprivrede“. OPG-ovi i Agro Hub moraju igrati glavnu ulogu u inovacijama $\mathrm{i}$ istraživanju sustava podrške odlučivanja i tehničkih rješenja postojećih problema. Sveukupna tehnička rješenja moraju postati pametnija i integrirana u sustave upravljanja 
OPG-ova, kako bi se podržalo OPG-ove i Agro Hub u njihovom boljem odlučivanju i vođenju poljoprivredne proizvodnje. Dodanu vrijednost ovih rješenja treba testirati, potvrditi i pokazati u praksi na komercijalnim OPG-ovima koja predstavljaju različite kulture i zemljopisna područja. OPG-ovi bi trebali biti aktivno uključeni u razvoj pametne poljoprivrede, kako bi se osigurala jasna korist na razini proizvodnje, u smislu poboljšane produktivnosti i održivosti okoliša te profita. Obuka za pametne tehnologije za OPG-ove i Agro Hub od ključne je važnosti. Sami poljoprivredni proizvođači moraju potaknuti demonstraciju odgovarajuće tehnologije kako bi se osiguralo široko usvajanje alata pametne poljoprivrede. S obzirom da na otoku Hvaru ne postoje sustavi pametne poljoprivrede, nužno je edukacijom približiti postojećim OPG-ovima mogućnosti koje ona pruža. Najbolji je primjer efikasnog sustava unutar granica RH „AGRIVI“ softver za pametnu poljoprivredu. On omogućava veliki broj operacija koje mogu uvelike unaprijediti poljoprivrednu proizvodnju. „Agrivi softver za upravljanje poljoprivrednom proizvodnjom omogućuje planiranje, nadzor i analizu svih aktivnosti na poljima" (Agrivi, 2020). Često nerentabilna proizvodnja i planiranje poljoprivrede imaju uzrok u nedovoljnoj analizi i planiranju. Predloženi model Agro Hub-a može povezati putem sustava svoje kooperante i na taj način poboljšati efikasnost, voditi centralnu nabavu repromaterijala, analizirati financijsku efikasnost označavanja i praćenje proizvoda. Sve to podiže poljoprivrednu proizvodnju na viši nivo razvoja. Budući da Hvar ima oskudne resurse, od velike je važnosti pokrenuti implementaciju sustava pametne poljoprivrede. Pri tome Agro Hub treba imati ključnu ulogu u edukaciji OPGova za korištenje sustava (Slika 3).

Jedan je od glavnih temelja povećanja poljoprivredne proizvodnje na otoku Hvaru izgradnja otkupno-distribucijskog centra. Na upit o spremnosti ulaganja u povećanje poljoprivredne proizvodnje ukoliko se otvori takav centar, 57 od 75 ispitanika odgovorilo je potvrdno (Tablica 14). S obzirom da je i najveći broj ispitanika detektirao problem nedostatka distribucijskog centra može se zaključiti da model Agro Hub-a predstavlja adekvatno rješenje za hvarske poljoprivrednike. Isto tako je 44 od 75 ispitanika odgovorilo da bi im osnivanje distribucijskog centra „u znatnoj mjeri pomoglo“, a 23 od 75 ispitanika odgovorilo je da im je to od „ključne važnosti“ (Tablica 15). Podrška aktivnostima na uspostavljanju Agro Hub-a može se usredotočiti na traženje informacija i opredjeljenje jedinica lokalne samouprave (JLS) otoka Hvara u identificiranju „с̌vorišta“ lokacije radi uspostavljanja ODL-a. Osnivanje Agro Hub-a doprinosi razvoju poljoprivredne proizvodnje, smanjuje poljoprivredne troškove, osigurava kupnju, plasman robe i omogućava OPG-ovima veću financijsku dobit. Stoga ne čudi da se 71 ispitanik od 75 izjasnilo da bi koristili distribucijski centar kada bi bio osnovan (Tablica 16). Na taj način OPG-ovi postaju konkurentni i stvaraju temelje za povećanje poljoprivredne proizvodnje. Jer ukoliko prihvatni kapaciteti nisu dovoljni za prihvat potrebne količinu voća i povrća na čuvanje od proizvođača, voćarska i povrtlarska proizvodnja izložene su sezonskim oscilacijama cijena, riziku i dugoročno razvojnoj nesigurnosti. U usporedbi sa zadrugama, Agro Hub predstavlja drugačiji poslovni model jer su oni primarno usmjereni na dobit, a nisu vođeni principom solidarnosti i uzajamne pomoći 
koji su u srži zadruge. To otvara mogućnost ulaganja privatnog sektora u ovaj segment poljoprivredne djelatnosti. Agro Hub (Slika 4) može biti uspostavljen i na principu javno-privatnog partnerstva: JLS osigurava prostor ili zemljište za zgradu, OPG-ovi su dobavljači robe, a investitori mogu sudjelovati u izgradnji ili opremanju Agro Hub-a. $\mathrm{Na}$ taj su način OPG-ovi postaju partneri i mogu osigurati povoljnije mogućnosti u svome poslovanju.

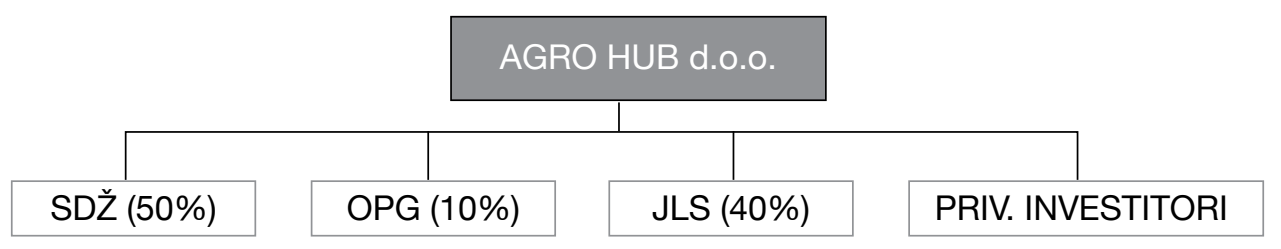

Slika 4. Financijski model osnivanja Agro Hub-a (Izvor: autori)

Model distribucijskog centra iz Velike Gorice dobar je prikaz zajedničkog djelovanja JLS-a i poljoprivrednih proizvođača. „Tvrtka Distributivni centar za voće i povrće d.o.o. iz Velike Gorice osnovana je 2008. na inicijativu Zagrebačke županije (79,99\%), Grada Velika Gorica $(15,60 \%)$ i poljoprivredne zadruge Zagrebački voćnjaci $(4,41 \%)$ s namjerom da postane centralno mjesto koje će omogućiti koncentraciju ponude voća i povrća poljoprivrednih proizvođača s područja Zagrebačke županije te okolnih županija" (Zagrebačka županija, 2020). Hvarski bi model isto tako trebao objediniti napore otočnih JLS-a i poljoprivrednih proizvođača u pronalasku prikladnog modela za unapređenje otočne proizvodnje. Kao što je već naznačeno, otok Hvar ima nepovoljnije uvjete razvoja poljoprivrede od kopnenog dijela i stoga predloženi model mora odgovoriti na sve izazove koji se javljaju na otoku Hvaru.

U postrojenje Agro Hub-a spada (Slika 5): prijem proizvoda, sortirnica, prostor za ambalažu, rashladne komore s adekvatnim hodnicima, sušionica proizvoda i proizvodne linije za preradu proizvoda. Važno je napomenuti da se razvoj Agro Hub-a treba razvijati po fazama kako bi se osigurao kontinuirani rast prema raspoloživoj količini proizvoda i ekonomičnost procesa.

Pod robnom markom podrazumijevamo naziv, izraz, slogan, znak, simbol, lik, dizajn proizvoda, odnosno njihovu kombinaciju, kojima identificiramo proizvod jednog ili skupine proizvođača i razlikuje ih od konkurencije (Kotler i sur., 2005). Starogradsko polje u kontinuiranoj je upotrebi kao poljoprivredno područje i zasađeno je istim kulturama već 2.400 godina, što svjedoči o kontinuitetu i trajnosti funkcije kroz stoljeća. Starogradsko polje primjer je vrlo starog tradicijskog krajolika koji je danas ugrožen modernim ekonomskim razvojem, posebno zbog depopulacije sela i napuštanja tradicijskog načina obrade zemljišta. Javna ustanova Agencija za upravljanje Starogradskim poljem 2008. godine je pokrenula je projekt zaštite robne marke poljoprivrednih proizvoda Plodovi polja koji dolaze s lokaliteta uvrštenog na popis svjetske kulturne i prirodne baštine UNESCO-a, dakle s područja Starogradskog polja (Agencija za upravljanje Starogradskim poljem, 2020b). Iako je nužno poboljšati kvalitetu i kontrolu robne marke, može 
se zaključiti da je to dobar primjer i pokušaj podizanja vidljivosti hvarske poljoprivredne proizvodnje. U anketno pitanje o označavanju proizvoda, 71 od 75 ispitanika odgovorilo je potvrdno tj. da je nužno označavanje proizvoda (Tablica 17).
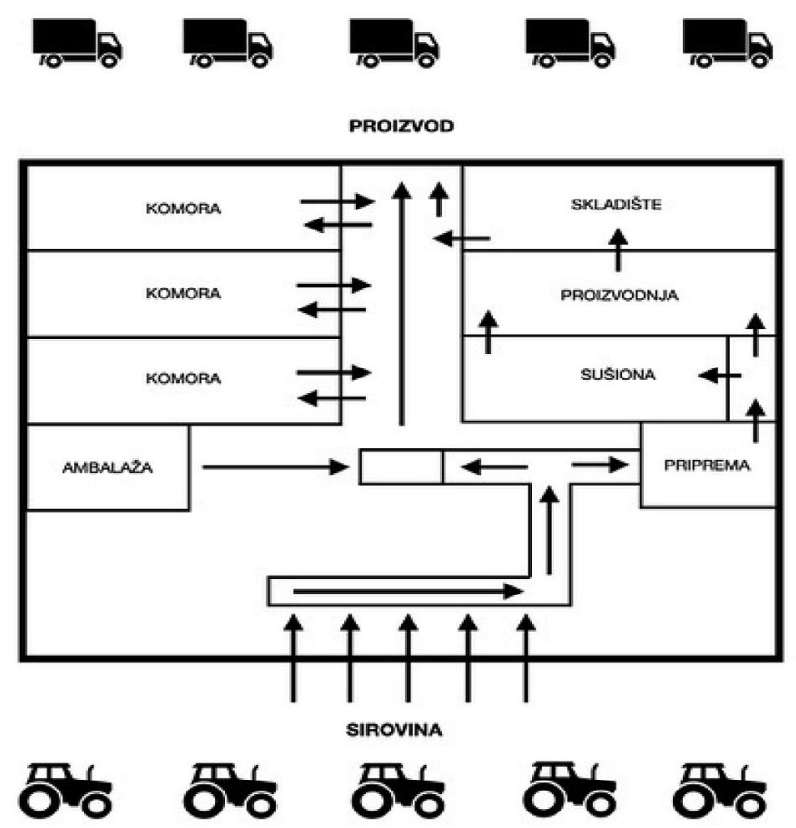

Slika 5. Mogući prostorni smještaj Agro Hub-a sa potrebnim tehničkim postrojenjem (Izvor: autori)

Isto tako, otok Hvar mora uložiti dodatne napore u pomoći lokalnim OPG-ovima i zaštiti maslinovog ulja, vina i lavande kao prepoznatljivih otočnih proizvoda. Ukupno 71 od 75 ispitanika slaže se da je nužno tražiti geografsko podrijetlo za ulje i vino (Tablica 18).

Ogledni primjeri geografske zaštite maslinovog ulja mogu se vidjeti na otocima Krku, Korčuli, Braču i Cresu gdje su lokalna udruženja ishodila geografsko podrijetlo za svoja maslinova ulja (Toić, 2017).

Kada se govori o geografskom podrijetlu za pojedine proizvode opravdano se postavlja pitanje o isplativosti procesa. Prema Sladonja i sur. (2006) zaštita je proizvoda alat ruralnog razvoja jer je zaštićeni proizvod ograničen na područje određenog područja, pruža detaljne informacije o specifičnostima toga kraja, procesima proizvodnje, a sve to daje krajnjim kupcima potrebne informacije za prepoznavanje kvalitete proizvoda. Isto tako, ovo je posebno bitno za otočku proizvodnju za podizanje dodatne vrijednosti proizvoda i postizanje više cjenovne kategorije. Otočka proizvodnja nije konkurentna po površinama, stoga mora dati kvalitetne i prepoznatljive proizvode. Ulaskom Hrvatske u EU, potrebno je ulaganje dodatnih napora kako liberalizacija ne bi dodatno uništila hrvatsku poljoprivredu, a s druge strane iskorištavanje prednosti kvalitetnih proizvoda iz određenih krajeva RH (Perica i sur., 2010). 
Za kraj poglavlja diskusije može se zaključiti da dobiveni rezultati potvrđuju postavljena istraživačka pitanja u pogledu zainteresiranosti poljoprivrednih proizvođača za uspostavu novog opskrbnog lanca kao i da postoje potencijalne količine proizvoda za uspostavu proizvođačke organizacije. Naime, ukupna procijenjena vrijednost hvarske poljoprivrede iznosi oko 97 milijuna kuna. Za formiranje proizvođačke organizacije treba minimalno 5 proizvođača i dokazana prodaja proizvoda od $3.000 .000 \mathrm{kn}$. Potrebna vrijednost za proizvođačku organizaciju iznosi oko $3 \%$ procijenjene vrijednosti, što je ostvarivo ukoliko se formira Agro Hub kao kanal plasmana robe. Predloženi model u ovome radu daje osnovne smjernice i razmišljanje na koji način pristupiti problematici i preporuča dostupne alate.

\section{ZAKLJUČAK}

Kako bi se na otoku Hvaru osigurali uvjeti za unapređenje poljoprivredne proizvodnje nužno je uspostaviti tržišnu infrastrukturu za obiteljsko-poljoprivredna gospodarstva. Ključna se suradnja prvenstveno odnosi na relaciji jedinica lokalne samouprave i OPGova kako bi se uspostavio optimalni mehanizam unapređenja poljoprivrede na otoku Hvaru. Uloga bi JLS-a trebala biti u osiguranju prostora / zemljišta za izgradnju Agro Hub-a, kao i na stručnoj pomoći OPG-ovima u pogledu udruživanja i poticanja poljoprivredne proizvodnje. U radu je naveden primjer Distribucijskog centra d.o.o. iz Velike Gorice gdje je suradnja poljoprivredne zadruge Zagrebački voćnjaci, Grada Velike Gorice i zagrebačke Županije riješila glavne infrastrukturne probleme poljoprivrednika toga kraja. Omogućen je otkup, dorada i plasman proizvoda. S tom infrastrukturom članovi poljoprivredne zadruge dobili su preduvjet za osnivanje „proizvodne organizacije“ koja im omogućuje konkurentniju proizvodnju i plasman proizvoda, kao i pristup povoljnijim sredstvima Europske unije.

Agro Hub kao logističko-distributivna jedinica hvarske poljoprivrede bio bi nositelj poljoprivredne proizvodnje, edukacijom bi poticali korisnike na korištenje sustava pametne poljoprivrede te postali nosioci formiranja „robne marke“ kojom bi plasirali svoje proizvode. U radu je spomenut i primjer robne marke Plodovi polja koju je osmislila Javna ustanova Agencija za zaštitu Starogradskog polja, međutim nužno je poraditi na daljnjem unapređenju i naročito sustavu kontrole u dodjeli te markice.

Iz provedene ankete može se zaključiti da nepostojanje otkupnog centra na otoku u najvećoj mjeri sprječava lokalne OPG-ove za bolje investicije u poljoprivrednu proizvodnju, osiguravanje boljeg plasmana proizvoda i povoljnije financijske uvjete poslovanja. S obzirom na mišljenja izražena kroz anketu može se zaključiti da bi osnivanje Agro Hub-a bio dobar primjer u smjeru unapređenja poljoprivrede. To bi dovelo do udruživanja poljoprivrednih proizvođača jer nepovezani OPG-ovi nisu u stanju osigurati dugoročni rast i razvoj.

Značaj rezultata prikazanih u ovome radu u prvom se redu odnose na postavljena istraživačka pitanja oko korištenja ODL-a i Agro Huba koja su detaljnije analizirana kroz diskusiju, kao i prikaz ekonomskih pokazatelja poljoprivredne proizvodnje gdje je za- 
ključeno kako ukupna vrijednost poljoprivredne proizvodnje iznosi oko 97 milijuna kuna što daje potvrdu o mogućnosti osnivanja „proizvođačke organizacije“. Međutim, možda se važniji aspekt rada odnosi na sveobuhvatni prikaz hvarske poljoprivrede koji do sada nije temeljno analiziran što daje budućim istraživačima solidnu bazu za dodatnu analizu poljoprivredne proizvodnje otoka Hvara. Otok Hvar ima poljoprivredni potencijal, proizvodi se vrhunsko maslinovo ulje, vino, a hvarska lavanda otočka je karakteristika. Potreban je kvalitetan opskrbni lanac da bi ti proizvodi još bolje našli svoje tržište. Republika Hrvatska kroz Ministarstvo poljoprivrede osigurava financijske mjere kako bi poticali razvoj distribucijskih centara, povezivali OPG-ove i na taj način pomogli hrvatskom agraru. Predloženi model Agro Hub-a na otoku Hvaru može biti prvi pilot-projekt na otoku, a kasnije se model može proširiti i na druge kako bi se omogućilo i otocima da imaju približne uvjete kao i na kopnu. Vrlo važan podatak je i taj da je Starogradsko polje na listi UNESCO-ove svjetske baštine, što daje dodatnu vrijednost hvarskoj poljoprivredi i odličan temelj za brendiranje poljoprivrednih proizvoda.

\section{LITERATURA}

Agencija za plaćanja u poljoprivredi, ribarstvu i ruralnom razvoju (2019). Tražene kulture na Jedinstvenom zahtjevu iz 2019. URL: https://www.apprrr.hr/wp-content/ uploads/2019/07/Tra\%C5\%BEene-kulture-na-Jedinstvenom-zahtjevu-iz-2019.. xlsx (02.10.2020.)

Agencija za upravljanje Starogradskim poljem (2020a). Grčka kolonizacija Jadrana i otoka Hvara. URL: https://www.starogradsko-polje.com/grcka-kolonizacija-jadrana-i-otoka-hvara/ (27.04.2020.)

Agencija za upravljanje Starogradskim poljem (2020b). Plodovi polja. URL: https:// www.starogradsko-polje.com/plodovi-polja-projekti/ (27.02.2020.)

Agrishort (2018). Kratki opskrbni lanac. URL: http://agrishort.eu/hr/sto-je-kratki-opskrbni-lanac-kol (01.10.2020.)

Agrivi (2020). Industrije. URL: https://www.agrivi.com/hr/industrije/ (05.10.2020.)

Borzaga, C. i Galera, G. (2012). Promicanje razumijevanja zadruga u stvaranju boljeg svijeta. Zagreb: EURICSE i ICA.

Conceição Aguiar, L., DelGrossi, M. E. i Thomé, K. M. (2018). Short Food Supply Chain: Characteristics of a Family Farm. Ciência Rural, 48(5): 1-8. DOI: 10.1590/0103-8478cr20170775.

Cvitanić, A. (ur.) (1991). Hvarski statut. Split: Splitski književni krug.

Distributivni centar za voće i povrće d.o.o. (2020). O nama. URL: https://distributivni. eu/o-nama/ (05.11.2020.)

Državni zavod za statistiku RH (2003). Popis poljoprivrede 2003. URL: https://www. dzs.hr/hrv/censuses/agriculture2003/census_agr.htm (06.11.2021.)

EIP-AGRI (2015). EIP-AGRI Focus Group Innovative Short Food Supply Chain Management. Bruxelles: Europska komisija. URL: https://ec.europa.eu/eip/agriculture/ sites/default/files/eip-agri_fg_innovative_food_supply_chain_management_final_ 
report_2015_en.pdf (06.11.2020.)

Gajdić D, (2019). Definiranje i obilježja kratkih opskrbnih lanacapoljoprivredno-tehnoloških proizvoda. Ekonomska misao i praksa, 1: 381-408.

Hrvatska poljoprivredno-šumarska savjetodavna služba (2018). Katalog kalkulacija poljoprivredne proizvodnje 2018. Zagreb: Hrvatska poljoprivredno-šumarska savjetodavna služba. URL: https:/www.savjetodavna.hr/wp-content/uploads/2019/01/ KatalogKalkulacija2018.pdf (15.11.2020.)

Jarzębowski, S., Bourlakis, M. i Bezat-Jarzębowska, A. (2020). Short Food Supply Chains (SFSC) as Local and Sustainable Systems. Sustainability, 12(11): 4715. DOI: $10.3390 /$ su12114715.

Kirigin, B. i Slapšak, B. (2010). Farska hora. U: Poklečki Stošić, J. (ur.), Antički Grci na tlu Hrvatske (str. 135-137). Zagreb: Galerija Klovićevi dvori.

Kotler, P., Wong, V., Saunders, J. i Amstrong, G. (2005). Principles of Marketing. Harlow: Prentice Hall Europe.

Kovačević, M. (2018). Historijsko-geografski razvoj otoka Hvara (diplomski rad). Zagreb: Prirodoslovno-matematički fakultet Sveučilišta u Zagrebu.

Lokalna akcijska grupa Brač (2014). Razvojna strategija Lokalne akcijske grupe Brač 2014.-2020. godine. Supetar: Lokalna akcijska grupa Brač. URL: http://www.lagbrac.hr/wp-content/uploads/2016/10/LRS-LAG-Brac\%CC\%8C-2014-2020Master_Final-.pdf (25.02.2020.)

Ministarstvo poljoprivrede Republike Hrvatske (2020). Vodič za proizvođačke organizacije. Od inicijative do tržišne konkurentnosti. Zagreb: Ministarstvo poljoprivrede Republike Hrvatske. URL: https://ruralnirazvoj.hr/files/MPS-Brosura-200x200-Vodic-za-proizvodacke-organizacije.pdf (20.11.2020.)

Muzej Staroga Grada (2020). Starogradsko polje i Stari Grad - UNESCO Svjetska bastina. URL: https://msg.hr/starogradsko-polje-i-stari-grad-unesco-svjetska-bastina/ (02.12.2020.)

Nacionalna razvojna strategija (2020). Razvojni smjer 3. Zelena i digitalna tranzicija. Naslovnica. URL: https://hrvatska2030.hr/rs3/ (02.10.2020.)

National Agricultural Library (2020). Cooperatives and Food Hubs. URL: https://www. nal.usda.gov/legacy/afsic/cooperatives-and-food-hubs (10.12.2020.)

Perica, E., Cerjak, M. i Mikuš, O. (2010). Mogućnosti i potencijalne prijetnje hrvatskom maslinarstvu u Europskoj uniji. Pomologia Croatica, 16(3-4): 73-88.

Plan upravljanja Starogradski Ager. (2006). Ministarstvo kulture Republike Hrvatske, Uprava za zaštitu kulturne baštine, Konzervatorski odjel u Splitu. URL: https:// whc.unesco.org/uploads/nominations/1240.pdf (28.09.2020.)

Radinović, S., Par, V. i Gugić, J. (2004). Socioekonomski procesi u obiteljskim poljoprivrednim gospodarstvima Dalmacije. Društvena istraživanja, 13(4-5): 825-842.

Sladonja, B., Radulović, M., Brkić, K., Krapac, M. i Šetić, E. (2006). Oznaka izvornosti i zemljopisnog podrijetla maslina i maslinovog ulja u Hrvatskoj. Pomologia Croatica, 12(2): 175-188.

Stari Grad (2020). Hvar otok Unesca. Stari Grad i Starogradsko polje. URL: http:// stari-grad.eu/hr/hvar-otok-unesco/stari-grad-i-starogradsko-polje (10.11.2020.) 
Toić, U. (2017). Brendiranje (valorizacija) tradicionalnih poljoprivrednih i prehrambenih proizvoda. Krk: LAG Kvarnerski otoci. URL: http://kvarnerski-otoci.hr/ (10.12.2020.)

Vlada Republike Hrvatske (2019). Akcijski plan promoviranja i jačanja kratkih lanaca u opskrbi hranom ustanova iz javnog sektora za razdoblje 2019. i 2020. godine. Zagreb: Vlada Republike Hrvatske. URL: https://vlada.gov.hr/UserDocsImages//2016/ Sjednice/2019/O\%C5\%BEujak/148\%20sjednica\%20VRH//148\%20-\%2010. $\operatorname{pdf}(20.12 .2020$.)

Zagrebačka županija (2020). Prijedlog zaključka o primanju na znanje Izvješća Uprave o stanju Društva Distributivni cenatar za voći i povrće d.o.o. s Financijskim izvješćem za 2019. godinu. 20. sjednica Županijske skupštine Zagrebačke županije, 15. srpnja 2020. URL: https://www.zagrebacka-zupanija.hr/media/filer_public/75/96/75969f0728b7-4a6e-8737-592574302d4a/28_prijedlog_zakljucka_o_primanju_na_znanje_izvjesca_uprave_o_stanju_drustva_distributivni_centar_za_voce_i_povrce_ doo_s_financijskim_izvjescem_za_2019_godinu1.pdf (10.01.2021.)

Zakon o javnoj nabavi. Narodne novine, 120/16. 


\section{Prilog 1. Anketni upitnik}

1. Spol
1) Muški
2) Ženski

2. Dob
1) Ispod 20
2) Od 21 do 30
3) Od 31 do 40
4) $\mathrm{Od} 41$ do 50
5) Preko 50

3. Molimo navedite koji je glavni proizvod/usluga Vašeg OPG-a?
1) Voće
2) Povrće
3) Masline
4) Lavanda
5) Vinova loza
6) Ostalo

4. Primarni kupci Vaših proizvoda/usluga su:
1) Individualni potrošači
2) Trgovački lanci, trgovine
3) Hotelske kuće, restorani
4) Osobna potrošnja

5. Da li je Vaše gospodarstvo član nekog klastera/proizvođačke organizacije/ udruge/zadruge?
1) $\mathrm{Da}$
2) $\mathrm{Ne}$
3) Ostalo

6. Koji su najčešći problemi i prepreke $s$ kojima se susrećete u Vašem poslovanju, a specifični su za djelatnost koju obavljate?

1) Slaba poslovna povezanost gospodarstava u sektoru

2) Nerazvijena mreža otkupljivača i distribucije

3) Niske prodajne cijene

4) Visoke cijene inputa/repro materijala za proizvodnju

5) Nemogućnost ili kašnjenje u naplati za izdane robe/usluge

6) Ograničen pristup sredstvima za financiranje i investiranje

7) Nedostupnost informacija o mogućnostima potpora i sufinanciranja

8) Nedostatak stručnih specifičnih znanja za praćenje suvremene tehnologije proizvodnje

9) Nedovoljno raspoloživa sezonska radna snaga

10) Ograničene mogućnosti okrupnjavanja zemljišta 
7. Jeste li zainteresirani za treninge/edukacije/obuke a da je u svrhu unapređenja poslovanja OPG-a?

1) $\mathrm{Da}$

2) $\mathrm{Ne}$

8. Planirate li nova ulaganja unutar OPG-a ako se postavi novi distributivni lanac poljoprivredne proizvodnje?

1) $\mathrm{Da}$

2) $\mathrm{Ne}$

9. Po Vašem mišljenju koliko bi uspostava otkupnog distribucijskog centra sa mogućom doradom proizvoda na principu zadrugarstva, unaprijedilo razvoj Vašeg OPG-a?

1) Nimalo

2) U znatnoj mjeri

3) Od presudne važnosti

10. Da li bi koristili usluge distribucijskog centra kada bi bio osnovan?

1) $\mathrm{Da}$

2) $\mathrm{Ne}$

11. Smatrate li da treba brendirati proizvode Starogradskog polja pod jednom prepoznatljivom robnom markom?

1) $\mathrm{Da}$

2) $\mathrm{Ne}$

12. Jeste li za traženje geografskog porijekla za hvarsko maslinovo ulje i hvarsko vino sa područja otoka Hvara?
1) $\mathrm{Da}$
2) $\mathrm{Ne}$ 


\title{
ESTABLISHMENT OF THE ISLAND SUPPLY CHAIN AS A PREREQUISITE FOR AGRICULTURAL SUSTAINABLE DEVELOPMENT OF THE STARI GRAD PLAIN
}

\author{
Vinko Tarbušković, Želimir Dulčić, Stefan Gelineo and Milan Vranković
}

\begin{abstract}
The main goal of this paper is to answer two research questions: a) whther agricultural family farms are interested in establishing an efficient market chain, and b) whether the current economic value of agricultural production on the island of Hvar has the potential to form an organization of producers. Currently, the main characteristics of agricultural production on the island of Hvar are: low productivity, fragmented production, the lack of associations of family farmers, and the lack of purchase centers. The methodology used in the paper includes the analysis of available indicators of agricultural production on the island of Hvar and an online survey questionnaire that explored the opinions of agricultural producers. The results of the analysis justify the construction of a theoretical model of "the island distribution chain" and "Agro Hub". The model presented in the paper is based on successful examples of the development of distribution centers for agricultural products that could be applied on the island of Hvar. The implementation of the proposed model would greatly improve the agricultural production of Starigrad Plain, which has been continuous for 2,400 years, and thus included on the UNESCO World Heritage List.
\end{abstract}

Keywords: island distribution chain, Stari Grad Plain, family farms, Agro Hub, agricultural production

\section{ERSTELLEN EINER ABSATZKETTE AUF DER INSEL ALS VORAUSSETZUNG FÜR DIE NACHHALTIGE ENTWICKLUNG DER LANDWIRTSCHAFT VON STAROGRADSKO POLJE}

\author{
Vinko Tarbušković, Želimir Dulčić, Stefan Gelineo und Milan Vranković
}

\section{Zusammenfassung}

Das Hauptziel dieser Arbeit ist, zwei Forschungsfragen zu beantworten: a) Sind die landwirtschaftliche Familienbetriebe sind am Erstellen einer effizienten Handelskette interessiert? b) Hat der jetzige wirtschaftliche Wert der landwirtschaftlichen Produktion auf der Insel Hvar Potenzial, eine Produktionsorganisation zu formen? Den Ausgangspunkt bilden die Hauptmerkmale der Landwirtschaft auf Hvar in diesem Moment: niedrige Produktivität, zersplitterte Produktion, Fehlen von Vereinigungen landwirtschaftlicher Familienbetriebe und Fehlen von Ankaufstellen für landwirtschaftliche Produkte. Die in der Arbeit angewandte Methode beinhaltet eine Umfrage über die Stellungnahmen von Agrarproduzenten, sowie die Analyse vorhandener Kennzahlen über den Umfang der Agrarproduktion auf der Insel Hvar. Die Ergebnisse der Analyse rechtfertigen die Definierung des theoretischen Modells, das „eine Absatzkette auf der Insel und einen Agro Hub" enthält. Das definierte, in der Arbeit dargestellte, Modell beruht auf Beispielen der Entwicklung erfolgreicher Vertriebszentren für landwirtschaftliche Produkte und solche könnten auf der Insel Hvar funktionieren. Die Resultate der Implementierung des vorgeschlagenen Modells würden die landwirtschaftliche Produktion in Starogradsko polje, die schon kontinuierlich 2.400 Jahre dauert und deshalb zum UNESCO Welterbe gehört, in einem hohen Maße verbessern.

Schlüsselwörter: Absatzkette auf der Insel, Starogradsko polje, landwirtschaftlicher Familienbetrieb, Agro Hub, landwirtschaftlichen Produktion 